TARNOWSKIE STUDIA TEOLOGICZNE 34 (2015) NR 2, S. 71-85

http://dx.doi.org/10.15633/tst.1640

Maciej Kowalski OSST ${ }^{1}$

UNIWERSYTET PAPIESKI JANA PAWŁA II W KRAKOWIE

\title{
Kult św. Jana de Matha i św. Feliksa Walezego w Brewiarzu rzymskim
}

W ciągu roku liturgicznego - naucza II Sobór Watykański - Kościół wspomina wielu „męczenników oraz innych świętych, którzy dzięki wielorakiej łasce Bożej doszli do doskonałości, a osiągnąwszy już wieczne zbawienie, wyśpiewują Bogu w niebie doskonałą chwałę i wstawiają się za nami. W dniu ich narodzin dla nieba Kościół głosi misterium paschalne w świętych, którzy z Chrystusem współcierpieli i zostali z Nim współuwielbieni, przedstawia ich wiernym jako przykład, pociągający wszystkich przez Chrystusa do Ojca, a przez ich zasługi wyjednywa Boże dobrodziejstwa"².

Przywołany artykuł konstytucji o liturgii świętej wyraża sens kultu świętych i wskazuje na jego miejsce w modlitwie liturgicznej Kościoła․ Należy jednak pamiętać, że liturgiczny kult świętych jest zwieńczeniem długiego i złożonego postępowania. Świadczą o tym chociażby procesy kanonizacyjne trwające niekiedy kilka wieków. Nie mniej trudności nastręcza również sama redakcja tekstów liturgicznych o świętych, które w przeszłości zawierały elementy o charakterze legendarnym ${ }^{4}$. Echem tego problemu jest soborowe wezwanie do troski o podawanie żywotów świętych zgodnie z prawdą historyczną5.

${ }^{1}$ Mgr lic. Maciej Kowalski osst, doktorant Uniwersytetu Papieskiego Jana Pawła II w Krakowie, wychowawca w Wyższym Seminarium Duchownym oo. Trynitarzy w Krakowie. Zajmuje się popularyzacją wiedzy o zakonie trynitarzy.

2 Konstytucja o liturgii świętej Sacrosanctum Concilium, 104.

3 Por. H. Fros sJ, Wprowadzenie do mszy świętych, cz. 1, Warszawa 1980, s. 85.

4 Por. tamże, s. 88-89.

5 Por. Konstytucja o liturgii świętej Sacrosanctum Concilium, 92c. Zalecenie soborowe zostaje rozwinięte w ogólnym wprowadzeniu do Liturgii godzin: „Żywoty świętych należy uzgodnić z prawdą historyczną i mieć na uwadze istotną korzyść duchową czytających lub słuchających tego rodzaju tekstów. Trzeba się wystrzegać zwłaszcza wszystkiego, co może jedynie 
Wśród świętych czczonych w Kościele znajdują się dwaj założyciele Zakonu Przenajświętszej Trójcy: św. Jan de Matha i św. Feliks Walezy ${ }^{6}$. Poniżej przedstawimy ich drogę do chwały ołtarzy, licząc, iż pozwoli to zilustrować wspomniane problemy związane z kultem świętych. Ponadto przeanalizujemy ich przedsoborowe oficja brewiarzowe, a ściśle mówiąc, poświęcone im czytania hagiograficzne, wskazując przy tym zmiany, jakie się w nich dokonały w wyniku poszczególnych reform liturgicznych. Analiza ta pomoże przybliżyć sylwetki oraz cechy charakterystyczne świętości patriarchów zakonu trynitarskiego, których Kościół poprzez akt kanonizacji uznał za wzór do naśladowania i orędowników przed Bogiem7.

Godne podkreślenia jest to, iż nie chodzi tutaj o jakiekolwiek hagiografie, lecz właśnie o teksty liturgiczne, będące jedną z form publicznego kultu świętych oraz wyrazem wiary Kościoła. Sięgając do nich, pragniemy ukazać, w jaki sposób rozumiał on świętość obu założycieli oraz dlaczego zachęcał do oddawania im czci, o czym świadczy nie tylko oficjalne uznanie ich kultu, lecz przede wszystkim przygotowanie tekstów brewiarzowych i umieszczenie ich w Brewiarzu rzymskim.

\section{Historia kultu św. Jana de Matha i św. Feliksa Walezego}

Jan de Matha już za życia cieszył się wielkim szacunkiem. Z uznaniem o jego osobie wyraził się papież Innocenty III w bulli zatwierdzającej regułę trynitarską ${ }^{8}$. Kiedy zmarł, swoją cześć dla założyciela wyrazili trynitarze. Dowodzą tego szczegóły związane z jego pochówkiem. Chociaż pierwsze wspólnoty trynitarskie nie posiadały wielkiego majątku, co wynikało z surowych przepisów reguły, ciało założyciela zostało złożone w marmurowym

zadziwić. Należy uwydatnić duchowość właściwą danemu świętemu w sposób odpowiadający wymaganiom współczesnym oraz podkreślić jego znaczenie w życiu i duchowości Kościoła” (Liturgia godzin, t. 1, Pallotinum 2006, s. 75).

6 Tytuł założyciela w niniejszym artykule będziemy odnosić zarówno do św. Jana de Matha, jak i do św. Feliksa Walezego, ponieważ w ten sposób są nazywani w epoce, którą się zajmujemy. Dopiero w 1969 roku kapituła generalna zastrzegła tytuł założyciela jedynie dla św. Jana. Por. A. Witko, Trynitarze, Kraków 1999, s. 34.

Por. Kodeks prawa kanonicznego, Pallotinum 1984, kan. 1186.

8 Por. Inocencio, Operante divine dispositionis, [w:] Fuentes históricas de la Orden Trinitaria (s. XII-XV). Edición bilingüe. Selección y traducción de J.L. Aurrecoechea O.ss.T. y A. Moldón O.ss.T. Síntesis histórica de B. Porres Alonso O.ss.T., Córdoba 2003, s. 4-19. 
sarkofagu. Co więcej, jego szczątki pogrzebano w kościele. Stało się tak, mimo iż ówczesne prawo kościelne pozwalało na to tylko w wyjątkowych przypadkach ${ }^{9}$.

O wiele trudniej jest ukazać pierwsze przejawy kultu św. Feliksa. Trudność ta wynika $\mathrm{z}$ braku dokumentów na jego temat ${ }^{10}$. Wszystko, co o nim wiemy, opiera się na kilku źródłach. Jednym z bardziej interesujących jest dokument przytoczony w dziele xviı-wiecznego francuskiego historyka o nazwisku Du Plessis, będący umową pomiędzy trynitarską wspólnotą z Cerfroid a biskupem diecezji Meaux (na której terenie znajdował się klasztor trynitarzy) i kapitułą katedralną. Na mocy tego aktu obie wspólnoty zobowiązywały się do uczestnictwa $\mathrm{w}$ modlitwach $\mathrm{w}$ konkretne dni. Wspólnota z Cerfroid obiecywała przybyć do Meaux w święto Wniebowzięcia i Narodzin Najświętszej Maryi Panny, biskup natomiast oraz kanonicy katedralni zobowiązywali się odwiedzić Cerfroid w niedzielę Przenajświętszej Trójcy i Feliksa wyznawcy ${ }^{11}$.

Przytoczone powyżej przykłady nie zmieniają faktu, iż pamięć o założycielach nie trwała długo. W pierwszym kalendarzu zakonnym, zatwierdzonym przez kapitułę generalną w roku 1247, pojawia się uroczyste święto „naszego świętego ojca Augustyna”. Nie ma natomiast żadnej wzmianki o święcie ku czci założycieli. Nie zachowała się też dokumentacja z procesu kanonizacyjnego Jana de Matha i Feliksa Walezego, jaki rzekomo rozpoczęto w ciągu pierwszych 400 lat po śmierci obydwu ${ }^{12}$.

Na próby przywrócenia pamięci o założycielach trzeba było czekać kilkaset lat. Szczególnie cenne pod tym względem są xv-wieczne opowiadania o początkach zakonu trynitarskiego autorstwa ministra generalnego, a jednocześnie wielkiego humanisty, Roberta Gaguina ${ }^{13}$. Wkrótce potem, pod koniec wieku xvi, trynitarze z prowincji portugalskiej jako pierwsi podjęli

9 Por. G. Llona Rementería, Fundador y redentor Juan de Mata, Salamanca 1994, s. 435.

${ }^{10}$ Wokół osoby św. Feliksa od lat toczy się wielka dyskusja. Niektórzy autorzy zaczęli wręcz podważać jego historyczność. Polemikę z nimi podejmuje między innymi o. Bernardino Fratini w swojej monografii: S. Felice de Valois nella tradizione dell'Ordine Trinitario, Roma 1998, zwłaszcza s. 152-210.

${ }^{11}$ Por. G. Cipollone, Studi intorno a Cerfroid, prima casa dell'Ordine Trinitario (1198-1429), Roma 1997, s. 46.

${ }^{12}$ Por. A. O. D'Errico, The Trinitarians. An overview of their eight hundred years to God and humanity, Roma [b.r.], s. 384-385.

${ }^{13}$ Por. G. Llona Rementería, Fundador y redentor Juan de Mata, dz. cyt., s. 438. 
wysiłki zmierzające do uznania ich kultu publicznego ${ }^{14}$. Wreszcie po tym, jak Urban VIII w 1625 roku wydał nowe, bardzo restrykcyjne prawo dotyczące kultu świętych, trynitarze trzewiczkowi i bosi wspólnie zabiegali o oficjalne uznanie za świętych Jana i Feliksa. Wstępnym warunkiem do zatwierdzenia kultu kogoś, kto tylko zwyczajowo był uważany za świętego, było udowodnienie, że odbiera on kult od niepamiętnych czasów. Trynitarze zachęceni „sukcesem” wielu zakonów, których założyciele zostali uznani za świętych, rozpoczęli starania o kanonizację Jana i Feliksa ${ }^{15}$.

W 1630 roku w Rzymie rozpoczął się proces mający potwierdzić kult założycieli od niepamiętnych czasów. Ojciec Jerónimo Vélez został wysłany do Rzymu z relacjami zebranymi w Toledo, Segowii, Ubedzie i Burgos. Sądzono, że w tych miastach zachował się żywy kult obu założycieli. Zgromadzone dokumenty okazały się jednak niewystarczające i proces wstrzymano aż do roku 1644, kiedy wybrano Innocentego x. Papież zezwolił, aby święto obydwu założycieli obchodzono w klasztorach trynitarskich w Paryżu, Walencji i Orihueli, a następnie rozszerzył ten przywilej na wszystkie domy w Hiszpanii ${ }^{16}$.

Trynitarze byli jednak niezadowoleni z uzyskanego zezwolenia, chcieli bowiem wyraźnej deklaracji papieża o kulcie założycieli od niepamiętnych czasów. W tym celu w 1659 roku trynitarze bosi wybrali na prokuratora generalnego o. Juana de la Concepción. Głównym zadaniem nowego przedstawiciela zakonu przy Stolicy Świętej było doprowadzenie do ponownego otwarcia procesu. W Rzymie o. Juan przedstawił nie tylko świadectwa zebrane w 1630 roku, lecz także krótkie życiorysy Jana i Feliksa z dedykacją dla papieża Aleksandra viı oraz prośbę o to, aby Święta Kongregacja Obrzędów ponownie rozpatrzyła ich sprawę. Papież odpowiedział pozytywnie na ten wniosek. Nowe kanoniczne dochodzenie, które nadzorował kard. Marzi Ginetto, zostało przeprowadzone w Burgos, Walencji, Granadzie, Kordowie, Madrycie oraz innych miastach ${ }^{17}$.

W wyniku przeprowadzonego procesu 31 lipca 1665 roku kard. Ginetto oświadczył, że Jan de Matha i Feliks Walezy odbierali cześć i kult od nie-

\footnotetext{
${ }^{14}$ Por. tamże.

15 Por. A. O. D'Errico, The Trinitarians, dz. cyt., s. 385.

${ }_{16}$ Por. tamże.

17 Por. tamże, s. 385-386.
} 
pamiętnych czasów ${ }^{18}$. Rok później, 14 sierpnia 1666 roku, dekret potwierdzający w tej sprawie wydała Święta Kongregacja Obrzędów. Papież Aleksander viI zatwierdził ów dokument 21 października 1666 roku, co w praktyce oznaczało kanonizację równoważną ${ }^{19}$.

Po ogłoszeniu założycieli świętymi trynitarze rozpoczęli starania o uzyskanie zezwolenia na sprawowanie mszy świętej i oficjum ku ich czci. Stolica Święta zapewniła taką możliwość już w 1669 roku. Równie szybko, bo 24 stycznia 1671 roku, imiona obydwu świętych zostały wpisane do Martyrologium rzymskiego: św. Jana pod datą 17 grudnia, a św. Feliksa 4 listopada ${ }^{20}$. Nadal jednak brakowało własnych tekstów liturgicznych, które miałyby być czytane w miejsce tekstów wspólnych o wyznawcach niepapieżach. Zatwierdził je papież Klemens x 17 maja 1673 roku ${ }^{21}$. Tymczasem pojawił się jeszcze jeden problem. Okazało się, że wspomnienia nowych świętych zbiegały się z początkiem bezpośredniego przygotowania do Święta Narodzenia Pańskiego oraz ze wspomnieniem św. Karola Boromeusza, co uniemożliwiało ich obchodzenie. W związku z tym kongregacja, na prośbę o. Felipe de Jesús, prokuratora generalnego trynitarzy bosych, pismem z 14 listopada 1676 roku postanowiła przenieść je na najbliższe wolne dni z dziewięcioma czytaniami. Ostatecznie liturgiczne wspomnienie św. Jana de Matha wyznaczono na 8 lutego, a św. Feliksa Walezego na 20 listopada. Brewe Innocentego XI $\mathrm{w}$ tej sprawie nosi datę 30 lipca 1679 roku $^{22}$.

Na koniec trynitarze podjęli starania o to, aby święto ich założycieli objęło cały Kościół. Z wnioskiem w tej sprawie zwrócił się do kongregacji o. Pedro de Jesús, prokurator generalny trynitarzy bosych, podkreślając, że było ono już obchodzone w wielu krajach katolickich ${ }^{23}$. Papież Innocenty xII przychylił się do tej prośby i 19 maja 1694 roku rozszerzył liturgiczny kult Założycieli Zakonu Przenajświętszej Trójcy na cały Kościół. W efekcie msza

${ }_{18}$ Por. B. Fratini osst, S. Felice de Valois nella tradizione dell'Ordine Trinitario, dz. cyt., S. 262-264.

19 Por. P. Aliaga osst, Zwiastuni Chrystusa Odkupiciela, Kraków 2013, s. 33.

${ }^{20}$ Por. B. Fratini osst, S. Felice de Valois nella tradizione dell'Ordine Trinitario, dz. cyt., s. $269-270$.

${ }^{21}$ Por. G. Llona Rementería, Fundador y redentor Juan de Mata, dz. cyt., s. 446.

${ }^{22}$ Por. B. Fratini osst, S. Felice de Valois nella tradizione dell'Ordine Trinitario, dz. cyt., s. 271-272.

${ }^{23}$ Między innymi w Polsce. Dekret w tej sprawie Święta Kongregacja Obrzędów wydała 21 stycznia 1690 roku. Por. tamże, s. 276-277. 
święta i oficjum z własnymi tekstami o św. Janie de Matha i św. Feliksie Walezym zostały włączone do Brewiarza i Mszału rzymskiego i pozostały w nich aż do roku 1969. W wyniku przeprowadzonej wówczas reformy kalendarza liturgicznego przeniesiono je do kalendarza własnego Zakonu Przenajświętszej Trójcy ${ }^{24}$. W obowiązującym brewiarzu zakonnym, wydanym po II Soborze Watykańskim, pod datą 4 listopada możemy przeczytać: „św. Feliksa Walezego, prezbitera, Współzałożyciela Zakonu Przenajświętszej Trójcy, wspomnienie obowiązkowe"25. Pod datą 17 grudnia natomiast znajdujemy informację następującej treści: „Naszego Świętego Ojca Jana de Matha, prezbitera, Założyciela Zakonu Przenajświętszej Trójcy, uroczystość”26.

\section{Oficjum o św. Janie de Matha i św. Feliksie Walezym}

Jak powiedzieliśmy powyżej, oficjum ku czci Świętych Założycieli Zakonu Przenajświętszej Trójcy z własnymi tekstami zostało włączone do Brewiarza rzymskiego w 1694 roku. W Kościele obowiązywał wówczas brewiarz wydany $\mathrm{W} 1568$ roku na polecenie Piusa $\mathrm{v}^{27}$. Żywoty obydwu świętych umieszczono w matutinum, które składało się z trzech nokturnów, $\mathrm{z}$ trzema psalmami i trzema czytaniami każdy. Trzy czytania hagiograficzne obejmował nokturn drugi $^{28}$. W takiej formie przetrwały one do roku 1911, kiedy Pius x w bulli Divino afflatu dowartościował temporale ${ }^{29}$. W rezultacie $\mathrm{w}$ pewnych okolicznościach nie czytano trzech czytań hagiograficznych. Zamiast nich było wolno przeczytać historyczne Czytanie Ix, będące skróconym życiorysem ${ }^{30}$. 25 lipca 1960 roku Jan XXIII w motu proprio Rubricarum instructum polecił między innymi zredukować matutinum do jednego nokturnu, składającego się z dziewięciu psalmów oraz trzech czytań ${ }^{31}$. W ten sposób dotychczasowe trzy czytania hagiograficzne całkowicie zniknęły z brewiarza, a krótszy życiorys, opracowany na potrzeby reformy Piusa $\mathrm{x}$, stał się obowiązującym.

${ }^{24}$ Por. tamże, s. 277-278.

${ }_{25}$ Proprium Liturgiae Horarum pro Ordinis Sanctissimae Trinitatis, Romae 1976, s. 133.

${ }_{26}$ Tamże, s. 160.

27 Por. B. Nadolski tchr, Liturgika, t. 2: Liturgia i czas, Poznań 1991, s. 197.

${ }_{28}$ Por. Nokturn, [w:] Leksykon liturgii, opr. B. Nadolski tchr, Poznań 2006, s. 1051.

${ }_{29}$ Por. B. Nadolski Tchr, Liturgika, t. 2, dz. cyt., s. 197.

${ }^{30}$ Por. Breviarium Romanum, Pars hiemalis, Ratisbonae et Romae 1916, s. 823-824; Breviarium Romanum, Pars autumnalis, Ratisbonae et Romae 1916, s. 763.

${ }^{31}$ Por. B. Nadolski Tchr, Liturgika, t. 2, dz. cyt., s. 198. 


\section{Czytania hagiograficzne o św. Janie de Matha}

Trzyczęściowy opis życia św. Jana de Matha w Breviarium Pianum otwiera Czytanie Iv. Obejmuje ono pierwszy etap życia „założyciela Zakonu Przenajświętszej Trójcy [dla] Wykupu Niewolników" i zawiera informacje o miejscu jego narodzin, rodzinie, studiach oraz karierze naukowej. Z treści czytania dowiadujemy się, że św. Jan urodził się w Faucon, miasteczku położonym na terenie Prowansji, w pobożnej szlacheckiej rodzinie. By odbyć studia, musiał opuścić rodzinną miejscowość i udać się najpierw do Aix-en-Provence, a następnie do Paryża. Tam uzyskał tytuł doktora teologii; zasłynął wiedzą i cnotliwym życiem. Ponieważ biskup Paryża pragnął, aby jego przymioty stały się przykładem dla studentów, udzielił mu święceń kapłańskich. Uczynił to, mimo iż kandydat pokornie wzbraniał się przed przyjęciem tego sakramentu ${ }^{32}$.

Wiele miejsca, niemalże połowę objętości czytania, redaktor poświęcił opisowi mszy świętej prymicyjnej Jana - jak się okaże - wydarzenia przełomowego w jego życiu. Doświadczył on wówczas wizji, w której trynitarze widzą inspirację zakonu ${ }^{33}$. Tekst liturgiczny mówi, że podczas sprawowania Eucharystii ukazał mu się anioł ubrany w białe szaty, z krzyżem czerwono-niebieskim na piersi, z rękami skrzyżowanymi i położonymi na głowach niewolników znajdujących się po jego lewej i prawej stronie. Jeden z nich był chrześcijaninem, drugi natomiast Maurem ${ }^{34}$. Mistyczne przeżycie prze-

32 Por. Breviarium Romanum, Pars hiemalis, Mechliniae 1910, s. 462.

${ }_{33}$ Por. P. Aliaga osst, Zwiastuni Chrystusa Odkupiciela, dz. cyt., s. 15.

${ }^{34}$ Por. Breviarium Romanum, Pars hiemalis, Mechliniae 1910, s. 463. Ponieważ chodzi o fakt o znaczeniu fundamentalnym zarówno dla św. Jana de Matha, jak i dla zakonu trynitarskiego, należy zaznaczyć, że dzisiaj powszechnie przyjmuje się inny opis tego wydarzenia. Odnajdujemy go w datowanym na połowę XıII wieku anonimowym opowiadaniu Hoc fuit initium. Od relacji z brewiarza różni się on tym, że jest w nim mowa o ukazaniu się majestatu Bożego, a nie anioła: „Kiedy zaś powinien odprawić swoją pierwszą mszę, poprosił biskupa Paryża, a także opata św. Wiktora i swojego mistrza Prevostina, aby wzięli w niej udział [...]. Kiedy nadszedł dzień celebracji, odprawił mszę św., na której były obecne wszystkie ważne osobistości Paryża. Gdy zaś doszedł do momentu sekrety, żarliwie prosił Boga, o ile taka jest Jego wola, by wskazał $\mathrm{mu}$, do jakiego zakonu powinien wstąpić dla swojego zbawienia. Kiedy zaś podniósł swoje oczy ku niebu, ujrzał majestat Boży i Boga trzymającego w swoich rękach dwóch mężczyzn, którzy mieli łańcuchy na nogach, jeden z nich był czarny i zniekształcony, drugi biały i wychudzony" (Hoc fuit initium, [w:] Fuentes históricas de la Orden Trinitaria (s. XII-XV), dz. cyt., s. 224-227). Taki przebieg wypadków potwierdza mozaika umieszczona około roku 1210 nad wejściem głównym do pierwszego klasztoru trynitarzy w Rzymie na polecenie samego 
konało Jana o tym, że Bóg powołuje go do wykupu niewolników z rąk pogańskich ${ }^{35}$.

Pragnienie zrozumienia woli Bożej ${ }^{36}$ stanowi klamrę łączącą Czytanie IV z kolejnym. Doskonale widać to już w pierwszym zdaniu Czytania v, które zawiera informację o decyzji Jana, aby udać się w miejsce odosobnione i w ten sposób lepiej przygotować do realizacji powierzonego mu zadania ${ }^{37}$. Potwierdza to również wzmianka o spotkaniu z prowadzącym od wielu lat życie pustelnicze Feliksem Walezym, do którego Jan się przyłączył i wraz z nim „przez trzy lata ćwiczył się w modlitwie, kontemplacji i praktykowaniu wszelkich cnót" ${ }^{38}$.

Na szczególną uwagę w tej części zasługuje opis dwóch niezwykłych wydarzeń, jakie przyczyniły się do powstania i ostatecznego zatwierdzenia zakonu, i które wyjaśniają także pochodzenie jego nazwy oraz trynitarskiego habitu. Pierwsze $\mathrm{z}$ nich związane jest $\mathrm{z}$ osobami założycieli i według tradycji zakonnej miało miejsce w Cerfroid ${ }^{39}$. Gdy pewnego razu Jan i Feliks rozmawiali przy studni o Bożych sprawach, ukazał się im jeleń z krzyżem czerwono-niebieskim w porożu. Jan, widząc zdziwienie Feliksa, opowiedział mu o tym, co przeżył podczas swojej mszy świętej prymicyjnej. Odczytali to jako zachętę do jeszcze gorętszej modlitwy, a otrzymawszy we śnie trzykrotne napomnienie, postanowili udać się do Rzymu, aby uzyskać zatwierdzenie nowego zakonu, którego zadaniem miał być wykup niewolników ${ }^{40}$.

św. Jana de Matha, przedstawiająca Chrystusa z dwoma niewolnikami. Por. G. Cipollone, Il mosaico di S. Tommaso in Formis a Roma (ca. 1210). Contributo di iconografia e iconologia, Roma 1997, s. 32-35. Zdaniem Andrzeja Witki pojawienie się anioła we wspomnianym opisie wynika z błędu hagiograficznego, polegającego na pomieszaniu treści wizji św. Jana oraz objawienia, jakiego miał doświadczyć papież Innocenty III podczas mszy świętej na Lateranie. Por. A. Witko, Sztuka w służbie Zakonu Trójcy Świętej w siedemnastym i osiemnastym stuleciu, Warszawa 2002, s. 86.

35 Por. Breviarium Romanum, Pars hiemalis, Mechliniae 1910, s. 463.

${ }^{36}$ Św. Jan de Matha został obdarzony powołaniem założyciela. Jego realizacja opiera się na dialogu człowieka z Bogiem. Bóg objawia swój plan wobec człowieka, ale człowiek musi tę wolę Bożą rozpoznać i uwierzyć w nią, a to dokonuje się stopniowo. Por. K. Morajko ocist, Charyzmat zakonu cystersów. Studium historyczno-prawne, Kraków 2006, s. 248.

${ }^{37}$ Por. Breviarium Romanum, Pars hiemalis, Mechliniae 1910, s. 463. Owym miejscem, którego nazwy nie wymieniono, jest Cerfroid. Por. G. Cipollone, Studi in torno a Cerfroid, prima casa dell'Ordine Trinitario (1198-1429), dz. cyt., s. 40-42.

${ }^{38}$ Breviarium Romanum, Pars hiemalis, Mechliniae 1910, s. 463.

39 Por. A. Witko, Trynitarze, dz. cyt., s. 27.

${ }^{40}$ Por. Breviarium Romanum, Pars hiemalis, Mechliniae 1910, s. 463. 
Drugie wydarzenie wiąże się z Innocentym III, który zatwierdził regułę napisaną przez Jana de Matha oraz założony przez niego zakon. Nawiązując do tradycji zakonnej, czytanie wspomina o wizji, jaką miał papież podczas sprawowania Eucharystii w bazylice na Lateranie w święto św. Agnieszki: $\mathrm{w}$ trakcie podniesienia ujrzał anioła w bieli, z dwukolorowym krzyżem, wykupującego niewolników ${ }^{41}$. „Po tej wizji - jak czytamy - papież zatwierdził instytut i nakazał, aby nosił nazwę Zakonu Przenajświętszej Trójcy [dla] Wykupu Niewolników, proponując należącym do niego zakonnikom białe habity z krzyżem koloru czerwono-niebieskiego" ${ }^{42}$.

Czytanie vi obejmuje ostatni okres życia św. Jana de Matha, czyli czas po uzyskaniu papieskiego zatwierdzenia dla zakonu. W tych latach poświęcał się on rozszerzaniu swojego dzieła, prowadząc dynamiczną i zakrojoną na szeroką skalę działalność fundacyjną ${ }^{43}$. W czytaniu są wymienione z nazwy dwa klasztory trynitarskie wraz z krótkim opisem okoliczności ich założenia. Chodzi o kolebkę zakonu, czyli klasztor w Cerfroid w diecezji Meaux we Francji, oraz pierwszą fundację trynitarzy w Rzymie, czyli kościół i szpital św. Tomasza in Formis z przynależnymi do nich licznymi posiadłościami. Fundację obydwu klasztorów Jan nadzorował osobiście ${ }^{44}$. Papież Innocenty III, który przekazał Janowi kościół św. Tomasza, wręczył mu list polecający do króla Maroka, dzięki czemu mógł rozpocząć dzieło wykupu i wyruszyć do Hiszpanii. O tamtejszej jego działalności tekst traktuje obszernie, choć bardzo ogólnie ${ }^{45}$. Należy zaznaczyć, że powyższy opis, choć zawiera wiele ważnych informacji, nie zachowuje rzeczywistej chronologii wydarzeń ${ }^{46}$.

Życiorys kończy się opisem śmierci Jana w otoczeniu duchowych synów, którym poleca kontynuowanie dzieła wykupu: „zwoławszy braci i skutecznie zachęciwszy ich do dzieła wykupu wskazanego przez niebo, zasnął w Panu

\footnotetext{
${ }^{41}$ Por. tamże.

42 Tamże.

${ }^{43}$ O skuteczności podejmowanych przez niego działań świadczy między innymi to, że w momencie jego śmierci zakon posiadał już ponad trzydzieści klasztorów. Por. A. Witko, Trynitarze, dz. cyt., s. 34.

${ }_{44}$ Por. Breviarium Romanum, Pars hiemalis, Mechliniae 1910, s. 463.

${ }^{45}$ Por. tamże, s. 463-464.

${ }^{46} \mathrm{Z}$ przyjmowaną dzisiaj chronologią można się zapoznać, sięgając do: A. Witko, Trynitarze, dz. cyt.; P. Aliaga oss t, Zwiastuni Chrystusa Odkupiciela, dz. cyt.
} 
17 grudnia roku zbawienia 1213; a jego ciało zostało pochowane ze czcią w tym samym kościele św. Tomasza in Formis" ${ }^{47}$.

Taką strukturę - jak już wspomniano - oficjum o św. Janie zachowało w brewiarzu do początku xx wieku, kiedy to trzy czytania hagiograficzne stopniowo zaczęto zastępować jednym. Zredagowany na nowo życiorys oczywiście różni się od poprzedniego, ale wynika to przede wszystkim $\mathrm{z}$ różnej objętości obu tekstów. I tak, nic nie mówi na temat dzieciństwa i młodości św. Jana de Matha, wspominając jedynie, że „urodził się [on] w Faucon w Prowansji, z pobożnych i szlachetnych rodziców" ${ }^{48}$. Znacznie mniej miejsca poświęca opisowi mszy świętej prymicyjnej oraz wizji, jaką święty wówczas przeżył. Nie podaje żadnych okoliczności ani szczegółów tego wydarzenia. Informuje jedynie, że miało ono miejsce i że dzięki niemu Jan odkrył swoje powołanie ${ }^{49}$. Odpowiedzią na wezwanie do rewizji czytań ${ }^{50}$ wydaje się natomiast usunięcie wzmianki o wizji założycieli w Cerfroid oraz o wizji Innocentego III. Wspomniany zostaje jedynie pobyt Jana w miejscu odosobnionym i spotkanie z Feliksem, które zaowocowało decyzją o wyruszeniu do Rzymu ${ }^{51}$. Za tezą, że jest to próba wyeliminowania słabo udokumentowanych fragmentów, przemawia fakt, iż opis ostatniego okresu życia założyciela niewiele różni się od tego, jaki znajduje się w pierwotnym tekście; jest też prawie tej samej długości, stanowiąc ponad połowę objętości nowej redakcji ${ }^{52}$. Gdyby redaktor chciał zachować wspomniane treści, mógłby to uczynić chociażby kosztem ostatniej części czytania.

\section{Czytania hagiograficzne o św. Feliksie Walezym}

Życiorys św. Feliksa Walezego - w formie, w jakiej został włączony do Brewiarza rzymskiego - również składa się z trzech części. Czytanie IV dostarcza czytelnikowi ważnej informacji o pochodzeniu Feliksa. Dowiadujemy się

47 Breviarium Romanum, Pars hiemalis, Mechliniae 1910, s. 464.

${ }^{48}$ Breviarium Romanum, Tomus prior, Romae-Tornaci-Parisiis-Neo Eboraci 196o, s. 1126.

49 Por. tamże.

50 Troska o zgodność czytań hagiograficznych z prawdą historyczną była również jednym z elementów reform liturgicznych epoki przedsoborowej. Por. B. Nadolski Tchr, Liturgika, t. 2: Liturgia i czas, dz. cyt., s. 197-198.

${ }^{51}$ Por. Breviarium Romanum, Tomus prior, dz. cyt., s. 1126.

${ }^{52}$ Por. Breviarium Romanum, Pars hiemalis, Mechliniae 1910, s. 463-464; Breviarium Romanum, Tomus prior, dz. cyt., s. 1126-1227. 
z niego, że należał on do królewskiej rodziny Walezych. Fakt ten schodzi jednak na dalszy plan. Zgodnie bowiem $\mathrm{z}$ kanonem przyjętym w tekstach hagiograficznych akcent zostaje położony na ukazanie oznak jego przyszłej świętości. Aby osiągnąć ten cel, podkreśla się jego miłość względem potrzebujących: osobiście rozdawał jałmużnę żebrakom, posyłał im potrawy z własnego stołu oraz wielokrotnie ofiarowywał własne ubrania nędzarzom. Posiadał również dar proroctwa: wyprosił u swojego wuja, hrabiego Szampanii, łaskę dla skazanego na śmierć złoczyńcy, przepowiadając jego nawrócenie. Przyszłość potwierdziła prawdziwość jego słów ${ }^{53}$.

Kolejne czytanie jest kontynuacją pierwszej części życiorysu: „Kiedy upłynęła godna pochwały młodość, wskutek zamiłowania do kontemplacji rzeczy niebieskich zaczął tęsknić do samotności, najpierw jednak postanowił przyjąć święcenia, aby odsunąć od siebie wszelką nadzieję godności królewskiej, od odziedziczenia której według prawa salickiego nie był daleko. Wkrótce po wyświęceniu na kapłana i pobożnym odprawieniu pierwszej mszy udał się do pustelni, gdzie zachowując najwyższą wstrzemięźliwość, żywił się obfitością łask niebieskich" ${ }^{4}$. Wiemy już, że spotkał tam Jana oraz że po kilku latach życia eremickiego razem z nim wyruszył do Rzymu, aby prosić papieża o zatwierdzenie nowego zakonu ${ }^{55}$. Omawiane oficjum nieco inaczej opisuje te wydarzenia: „Tam spędził świątobliwie kilka lat razem ze św. Janem de Matha, doktorem z Paryża [...]; aż obaj pouczeni przez Boga za pośrednictwem anioła wyruszyli do Rzymu, aby uprosić u papieża specjalną regułę życia" ${ }^{36}$. Obie relacje zgadzają się natomiast co do tego, że anioł ukazał się Innocentemu III oraz że to skłoniło go do zatwierdzenia zakonu ${ }^{57}$.

Pierwsze lata istnienia zakonu także zostały różnie przedstawione w obydwu życiorysach. Dotyczy to czasu powstania pierwszego trynitarskiego klasztoru. Inaczej niż w oficjum o św. Janie - według którego klasztor w Cerfroid ufundowali założyciele po uzyskaniu papieskiej aprobaty - z życiorysu Feliksa, który nie podejmuje tematu okoliczności powstania fundacji, dowiadujemy się, że udał się on do Cerfroid, lecz tylko po to, aby powiększyć

53 Por. Breviarium Romanum, Pars autumnalis, Mechliniae 1910, s. 429.

54 Tamże, s. 429-430.

55 Zob. przytoczoną powyżej wersję z oficjum ku czci św. Jan de Matha.

${ }^{56}$ Breviarium Romanum, Pars autumnalis, Mechliniae 1910, s. 430.

57 Por. Breviarium Romanum, Pars hiemalis, Mechliniae 1910, s. 463; Breviarium Romanum, Pars autumnalis, Mechliniae 1910, s. 430. 
już istniejący klasztor. Tym samym, w świetle tego tekstu, jego rola polegała jedynie na przyczynieniu się do rozwoju pierwszej fundacji trynitarskiej ${ }^{58}$. Należy dodać, że ta wersja bardziej odpowiada prawdzie historycznej. Świadczy o tym chociażby fakt, iż wraz z dwoma innymi domami klasztor w Cerfroid został wymieniony w pierwszym papieskim dokumencie skierowanym do trynitarzy, który nosi datę 16 maja 1198 roku $^{59}$.

Oprócz informacji na temat roli św. Feliksa w historii Cerfroid w Czytaniu vi można znaleźć wzmiankę o szczególnej łasce, jaką miał on otrzymać w wigilię Narodzenia Najświętszej Maryi Panny: „ponieważ [...] Bóg tak sprawił, że wszyscy bracia, zmorzeni snem, nie wstali o północy na matutinum, Feliks, czuwając jak zwykle i wyprzedzając godziny, wszedłszy do chóru, spostrzegł na środku Najświętszą Dziewicę, ubraną w habit ozdobiony krzyżem zakonnym, w otoczeniu podobnie ubranych duchów niebieskich. Feliks, dołączywszy do nich, pod przewodnictwem Matki Bożej zaśpiewał boskie oficjum i zgodnie z prawem spełnił swój obowiązek"6o. Otrzymawszy zapewnienie anioła o zbliżającej się śmierci, zachęcał braci do miłości względem ubogich i niewolników ${ }^{61}$. Brewiarz nie wskazuje jednak dziennej daty jego śmierci ${ }^{62}$, podaje jedynie rok - 1212.

Pierwsze zmiany dotyczące treści czytań hagiograficznych w omówionym oficjum - podobnie jak w tekstach brewiarzowych o św. Janie de Matha wprowadziła dopiero reforma Piusa x. Podobnie jak poprzednio były one wymuszone przede wszystkim koniecznością zawarcia całego życiorysu w jednym czytaniu. Szczególną uwagę zwracają dwie z nich: usunięcie opisu dzieciństwa oraz lapidarna wzmianka o objawieniu się mu Matki Bożej ${ }^{63}$.

\section{Wnioski}

Podsumowując powyższe rozważania, należy stwierdzić, że historia kultu św. Jana de Matha i św. Feliksa Walezego jest bardzo dobrą ilustracją złożoności

\footnotetext{
${ }^{58}$ Por. Breviarium Romanum, Pars autumnalis, Mechliniae 1910, s. 430.

59 Por. Inocencio, Cum a nobis petitur, [w:] Fuentes históricas de la Orden Trinitaria (s. XII$X V)$, dz. cyt., s. $2-5$.

${ }^{60}$ Breviarium Romanum, Pars autumnalis, Mechliniae 1910, s. 430.

${ }^{61}$ Por. tamże.

${ }^{62}$ Według tradycji św. Feliks Walezy zmarł 4 listopada 1212 roku. Por. A. Witko, Trynitarze, dz. cyt., s. 34 .

${ }_{63}$ Por. Breviarium Romanum, Pars autumnalis, Ratisbonae et Romae 1916, s. 763.
} 
postępowania kanonizacyjnego oraz trudności, jakie mogą się pojawiać na różnych jego etapach. Pokazuje ona, że na rozwój kultu świętych duży wpływ ma zaangażowanie wielu osób. W naszym przypadku chodzi o trynitarzy, którzy wierząc w świętość swoich założycieli, najpierw podjęli starania o wyniesienie ich do chwały ołtarzy, a następnie o to, aby odbierali cześć w całym Kościele. Do osiągnięcia tego drugiego celu w znacznym stopniu przyczyniło się opracowanie oficjów brewiarzowych, a zwłaszcza czytań hagiograficznych. Jak wykazaliśmy, nie były one wolne od braków i pewnych sprzeczności. W dużym stopniu opierały się też na tradycji zakonnej. Mimo to zawarte w nich żywoty obydwu świętych przez kilka stuleci stanowiły źródło wiedzy na ich temat.

Warto zatem wskazać kilka cech charakterystycznych świętości Jana de Matha i Feliksa Walezego. Ich życie odznaczało się nieustannym pragnieniem poszukiwania i pełnienia woli Bożej, a także zaufaniem Bożej Opatrzności. Taka postawa często wymagała od nich wielu wyrzeczeń oraz zmiany własnych planów, a niejednokrotnie również umiejętności podejmowania odważnych decyzji. Świadczy o tym zarówno historia ich powołania, jak i wydarzenia związane z założeniem Zakonu Przenajświętszej Trójcy. Miłość Boga zawsze wiąże się z miłością bliźniego. Nic więc dziwnego, że obydwa oficja podkreślają również ich miłosierdzie oraz wrażliwość na ludzką nędzę. Na uwagę zasługuje jednak fakt, iż potrafili nadać tym pojęciom nowe znaczenie, łącząc je z nowatorskim dziełem wykupu niewolników chrześcijańskich, któremu poświęcili nie tylko swoje życie, lecz także nadali trwały, instytucjonalny charakter.

Bez wątpienia przykład świętości Jana i Feliksa nie stracił aktualności. Potwierdzeniem tego są chociażby informacje o kolejnych prześladowaniach chrześcijan. Natomiast same czytania hagiograficzne ku ich czci także dziś mogą stanowić źródło cennych informacji. Ich lektura może pomóc lepiej zrozumieć wiele dzieł sztuki trynitarskiej oraz wciąż żywych zwyczajów zakonnych. Do takich można zaliczyć na przykład czuwanie organizowane $\mathrm{w}$ wielu trynitarskich kościołach w nocy $\mathrm{z} 7$ na 8 września połączone $\mathrm{z}$ mszą świętą o północy, nawiązujące do objawienia Matki Bożej w Cerfroid.

Po analizie czytań hagiograficznych ku czci założycieli Zakonu Przenajświętszej Trójcy rodzi się również pytanie, na ile uzasadnione było usunięcie ich z kalendarza powszechnego i przeniesienie do kalendarza zakonnego? Doszło do tego w odpowiedzi na soborowe wezwanie, aby w całym Kościele 
wspominano jedynie „świętych o powszechnym znaczeniu” ${ }^{64}$. Komentując tę decyzję, o. Bernardino Fratini w swojej monografii o św. Feliksie przypomina, że dzieło wykupu zapoczątkowane przez założycieli Zakonu Przenajświętszej Trójcy odznacza się wielką trwałością i aktualnością w historii Kościoła ${ }^{65}$. O ile w odniesieniu do osoby św. Feliksa Walezego można mieć pewne wątpliwości natury historycznej, o tyle ten argument nie dotyczy św. Jana de Matha.

\section{Bibliografia}

Aliaga P. oss T, Zwiastuni Chrystusa Odkupiciela, Kraków 2013.

Breviarium Romanum, Pars autumnalis, Mechliniae 1910.

Breviarium Romanum, Pars autumnalis, Ratisbonae et Romae 1916.

Breviarium Romanum, Pars hiemalis, Mechliniae 1910.

Breviarium Romanum, Pars hiemalis, Ratisbonae et Romae 1916.

Breviarium Romanum, Tomus prior, Romae-Tornaci-Parisiis-Neo Eboraci 1960.

Cipollone G., Il mosaico di S. Tommaso in Formis a Roma (ca. 1210). Contributo di iconografia e iconologia, Roma 1997.

Cipollone G., Studi intorno a Cerfroid, prima casa dell'Ordine Trinitario (1198-1429), Roma 1997.

D’Errico A. O., The Trinitarians. An overview of their eight hundred years to God and humanity, Roma [b.r.].

Fratini B. osst, S. Felice de Valois nella tradizione dell'Ordine Trinitario, Roma 1998.

Fros H. sృ, Wprowadzenie do mszy świętych, cz. 1, Warszawa 1980.

Fuentes históricas de la Orden Trinitaria (s. XII-XV). Edición bilingüe. Selección y traducción de J.L. Aurrecoechea O.ss.T. y A. Moldón O.ss.T. Síntesis histórica de B. Porres Alonso O.ss.T., Córdoba 2003.

Kodeks prawa kanonicznego, Pallotinum 1984.

Leksykon liturgii, opr. B. Nadolski Tchr, Poznań 2006.

Liturgia godzin, t. 1, Pallotinum 2006.

Llona Rementería G., Fundador y redentor Juan de Mata, Salamanca 1994.

Morajko K. ocist., Charyzmat zakonu cystersów. Studium historyczno-prawne, Kraków 2006.

Nadolski B. Tchr, Liturgika, t. 2: Liturgia i czas, Poznań 1991.

Proprium Liturgiae Horarum pro Ordinis Sanctissimae Trinitatis, Romae 1976.

${ }^{64}$ Por. Konstytucja o liturgii świętej Sacrosanctum Concilium, 111.

${ }^{65}$ Por. B. Fratini osst, S. Felice de Valois nella tradizione dell'Ordine Trinitario, dz. cyt., s. 278. 
Sobór Watykański II, Konstytucja o liturgii świętej Sacrosanctum Concilium.

Witko A., Sztuka w służbie Zakonu Trójcy Świętej w siedemnastym i osiemnastym stuleciu, Warszawa 2002.

Witko A., Trynitarze, Kraków 1999.

\section{Streszczenie}

Celem artykułu jest przedstawienie kultu św. Jana de Matha i św. Feliksa Walezego w Brewiarzu rzymskim. Artykuł składa się z dwóch części. W pierwszej autor omawia drogę świętych do chwały ołtarzy oraz rozwój ich kultu liturgicznego, w drugiej natomiast analizuje poświęcone im czytania hagiograficzne z Brewiarza rzymskiego, zawierające wiele informacji na temat ich życia i świętości. Uwzględnia przy tym zmiany, jakie dokonały się w tych tekstach w wyniku kolejnych reform liturgicznych. Pozwala to nie tylko lepiej poznać sylwetki założycieli Zakonu Przenajświętszej Trójcy i Niewolników, lecz także ukazać ich znaczenie w różnych epokach.

\section{Słowa kluczowe}

kult świętych, Brewiarz rzymski, św. Jan de Matha, św. Feliks Walezy

\section{Summary}

\section{The cult of St. John de Matha and St. Felix de Valois in the Roman Breviary}

The purpose of the article is to present the cult of St. John de Matha and St. Felix de Valois in the Roman Breviary. The article consists of two parts. In the first part discussed is the way these saints gained the honors of the altar, and the development of their liturgical cult. In the second part author analyzes hagiographic readings from the Roman breviary dedicated to them, which contain a lot of information about their life and holiness. He also acknowledges changes in these texts resulting from the subsequent liturgical reforms. It allows not only to get a better understanding of the Founders of the Order of the Most Holy Trinity and of Captives but also to show their importance in different periods.

\section{Keywords}

cult of saints, Roman Breviary, St. John de Matha, St. Felix de Valois 